\title{
Transfer Teknologi Aeroponik Untuk Produksi Benih Kentang di Kelompok Tani Mulya Bersama, Kabupaten Banjarnegara, Propinsi Jawa Tengah
}

\author{
Eni Sumarni1, Asna Mustofa', Darini Sri Utami ${ }^{2}$, Siti Nurchasanah ${ }^{3}$ \\ ${ }^{1}$ Program Studi Teknik Pertanian. Jurusan TP. FAPERTA. Universitas Jenderal Soedirman Jl. dr. Suparno. \\ Karangbawang. Purwokerto Utara \\ 2 Jurusan Agroteknologi.FAPERTA. Universitas Jenderal Soedirman.
}

\begin{abstract}
Kelompok Tani Mulya Bersama memiliki kendala kontinuitas produksi benih kentang, penurunan kesuburan lahan dan penyakit nematoda sista kuning yang menyerang umbi kentang sehingga menurunkan produksi. Selain itu, penanaman kentang di lahan terbuka menghadapi cuaca ekstrem yaitu turunnya frost (embun beku) yang mematikan tanaman. Kelompok Tani memproduksi kentang dengan metode konvensional, hasil benih kentang rendah ( $<10$ umbi/tanaman), selain itu produksi benih kentang belum belum diperoleh nutrisi yang optimal. Kondisi ini menyebabkan hanya dapat memenuhi 30\% permintaan. Oleh karena itu tim Penerapan IPTEK memberikan transfer teknologi aeroponik dan nutrisi hasil paten untuk peningkatan jumlah benih kentang. Tujuan kegiatan ini: 1) Penerapan teknologi aeroponik produksi benih kentang, 2) Penerapan dan pengelolaan nutrisi hasil paten untuk peningkatan jumlah benih (> 25 umbi/tanaman). Metode yang dilakukan: 1) Transfer teknologi tahapan produksi benih kentang secara aeroponik dan membuat demplot, 2) Transfer teknologi pengelolaan nutrisi untuk produksi benih kentang secara aeroponik, dan 3) Pindah tanam bibit aeroponik serta pengamatan pertumbuhan dan perkembangan tanaman. Hasil kegiatan ini diperoleh bahwa pemahaman kelompok tani terhadap transfer teknologi ini mengalami peningkatan mencapai $85-87 \%$ dari sebelumnya 3-5\%. Keberlanjutan transfer teknologi ini mendapat dukungan dari Kelompok Tani Mulya Bersama dengan melakukan penambahan box aeroponik secara mandiri sebanyak 4 box (memiliki panjang $40 \mathrm{~m}$ ).
\end{abstract}

Keywords: aeroponik, benih kentang, dataran tinggi, greenhouse, nutrisi

\section{Pendahuluan}

Kelompok Tani Mulya Bersama Desa Sidomulya, RT.04/RW05, Kecamatan Batur, Kabupaten Banjarnegara, Propinsi Jawa Tengah merupakan salah satu usaha dibidang pertanian, berdiri sejak tahun 2012 dengan nomer badan hukum No. AHU0042995.AH.01.07. Komoditas yang dihasilkan berupa stek mini bibit kentang, benih kentang $\mathrm{G}_{0}$, benih kentang $\mathrm{G}_{1}$, benih kentang $\mathrm{G}_{2}$ dan sayuran lainnya (kubis, wortel, bawang daun, cabe Dieng) (Gambar 1). Produksi kentang merupakan komoditas unggulan, lokasi kelompok tani merupakan salah satu daerah sentra kentang di Propinsi Jawa Tengah.

* Corresponding author: arny0565@gmail.com

Received 1 November 2021; Received in revised form 11 November 2021; Accepted 12 November 2021

Available online 29 November 2021

Lembaga Penelitian dan PengabdianKepada Masyarakat

Universitas Lampung 
Produk kelompok Tani Mulya Bersama dipasarkan kebeberapa daerah, seperti wilayah dataran tinggi Dieng, Brastagi, Bumiayu Brebes, dan kawasan gunung Bromo Jawa Timur.

Namun, ada beberapa kendala yang dihadapi oleh kelompok tani Mulya Bersama dalam menjaga produktivitas, diantarnya yaitu topografi Banjarnegara dengan kemiringan lahan $45,04 \%$, maka produksi sayuran memiliki resiko terjadi erosi yang besar. Kondisi penanaman sayuran di lahan terbuka juga mendapatkan kendala ketika turunya frost (embun beku) pada cuaca ekstrem yang dapat mematikan tanaman sayuran di lahan terbuka (Gambar 2).

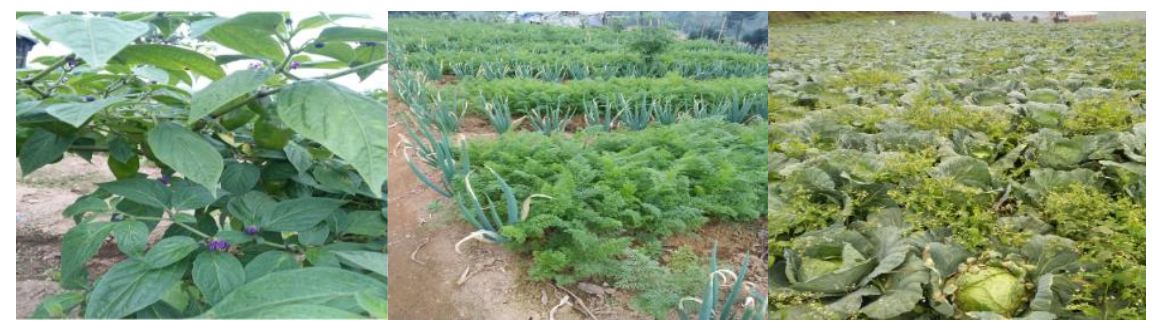

Gambar 1. Produksi sayuran di lahan terbuka (a) cabai Dieng, (b) bawang daun

Selain itu kondisi lahan yang kondisi kesuburannya menurun dan tingkat pencemaran yang tinggi akibat penggunaan pestisida yang berlebihan serta adanya penyakit NSK (Nematoda Sista Kuning) yang menurunkan produksi sayuran (Gambar 2). Produksi benih kentang juga menghadapi kendala ketersediaan nutrisi yang optimal untuk pertumbuhan dan perkembangannya. Benih kentang yang dihasilkan menggunakan metode kovensional hasilnya masih rendah yaitu sekitar 5-7 umbi/tanaman. Kondisi ini menyebabkan kelompok Tani Mulya Bersama hanya dapat memenuhi 30\% dari permintaan tiap bulanya, sehingga diperlukan transfer teknologi budidaya yang dapat membantu peningkatan jumlah benih kentang. Teknik produksi benih kentang yang dapat meningkatkan jumlah umbi adalah teknologi penanaman secara aeroponik $[1 ; 2 ; 3 ; 4 ; 5]$.
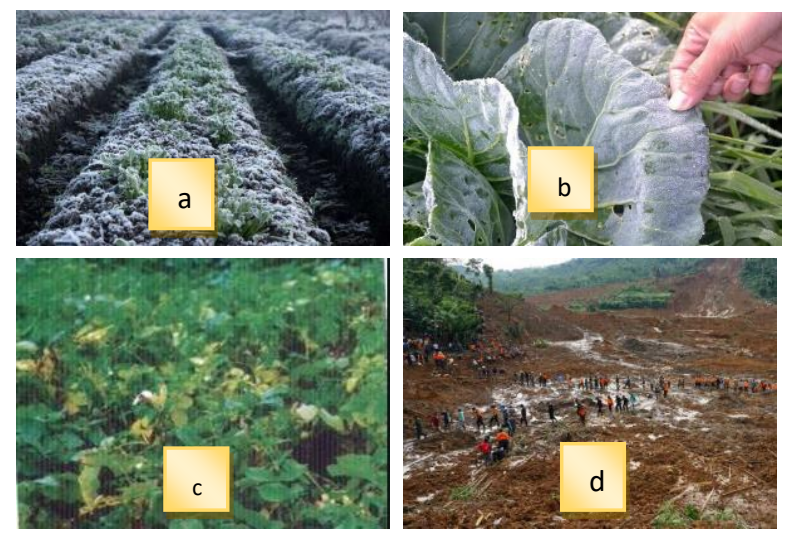

Gambar 2. Sayuran di lahan terbuka (a, b) kondisi ekstrem embun beku, (c) serangan nematoda sista kuning, (d) tanah longsor

Teknologi aeroponik dari tim pengabdian Universitas Jenderal Soedirman (Unsoed) telah diaplikasikan untuk menghasilkan benih kentang di dataran rendah, medium dan dataran tinggi $[6 ; 7 ; 8]$. Aplikasi di dataran tinggi dapat menghasilkan jumlah benih kentang $>25$ umbi/tanaman, bahkan ada yang mencapai 100 umbi/tanaman [8]. Penerapan nutrisi aeroponik untuk produksi kentang di lahan juga telah berhasil menghasilkan kentang dengan ukuran $L$ tinggi dari uji daya tumbuh benih kentang aeroponik dari dataran rendah [9]. Nutrisi tersebut telah mendapatkan sertifikat paten tahun 2019 dengan No. IDP000065162 [10]. Oleh karena itu tim pengabdian Unsoed melakukan kegiatan transfer teknologi melalui skema penerapan IPTEKS dari nutrisi hasil paten untuk mendukung peningkatan produksi benih kentang di Kelompok Tani Mulya Bersama, Desa Sidomulya 
Banjarnegara.

Peningkatan produksi benih kentang melalui pemberian pupuk kalium belum dapat meningkatkan produksi umbi. Perlakuan pupuk daun super $\mathrm{ACl}$ konsentrasi $3 \mathrm{cc} / \mathrm{l}$ pada varietas Atlantik meningkatkan tinggi tanaman 39.9\%, luas daun $77.2 \%$, jumlah umbi $61 \%$, dan diameter batang $8.9 \%$ dibandingkan tanpa pupuk daun. Namun, produksi umbi yang dihasilkan berkulit tipis, sehingga rentan terhadap busuk umbi. Variasi pertumbuhan dan hasil, serta kulit umbi kentang yang tipis diduga belum tercukupinya unsur nutrisi yang dibutuhkan. Produksi benih kentang dengan media steril (tanah dan pupuk kandang) pada seed bed di rumah kasa, hanya menghasilkan benih 1.5-3 umbi/tanaman [12]. Permasalahan di kelompok tani Mulya Bersama diberikan solusi melalui penerapan teknologi aeroponik dan nutrisi untuk produksi benih kentang secara aeroponik. Dari hal-hal diatas permasalahan yang perlu dipecahkan antara lain :

1. Bagaimana transfer teknologi produksi benih kentang secara aeroponik ?

2. Bagaimana transfer teknologi penerapan dan pengelolaan nutrisi aeroponik hasil paten untuk peningkatan jumlah benih kentang ?

3. Bagaimana evaluasi/monitoring penerapan IPTEKS yang dilakukan?

Pemecahan permasalahan yang dihadapi oleh kelompok Tani Mulya Bersama tersebut dilakukan melalui kegiatan trasfer teknologi dari tim pengabdi Unsoed melalui skema Penerapan IPTEKS. Transfer teknologi ini bertujuan: 1) Penerapan teknologi aeroponik produksi benih kentang, 2) Penerapan dan pengelolaan nutrisi untuk peningkatan jumlah benih.

\section{Methods}

\subsection{Waktu dan Lokasi}

Kegiatan ini dilakukan pada bulan Mei sampai Juni 2021. Peserta kegiatan adalah para anggota kelompok Tani Mulya Bersama yang berjumlah 10 orang. Kelompok Tani Mulya berlokasi di Dusun Sidomulyo, RT.04/RW05, Kecamatan Batur, Kabupaten Banjarnegara, Propinsi Jawa tengah (Gambar 3).

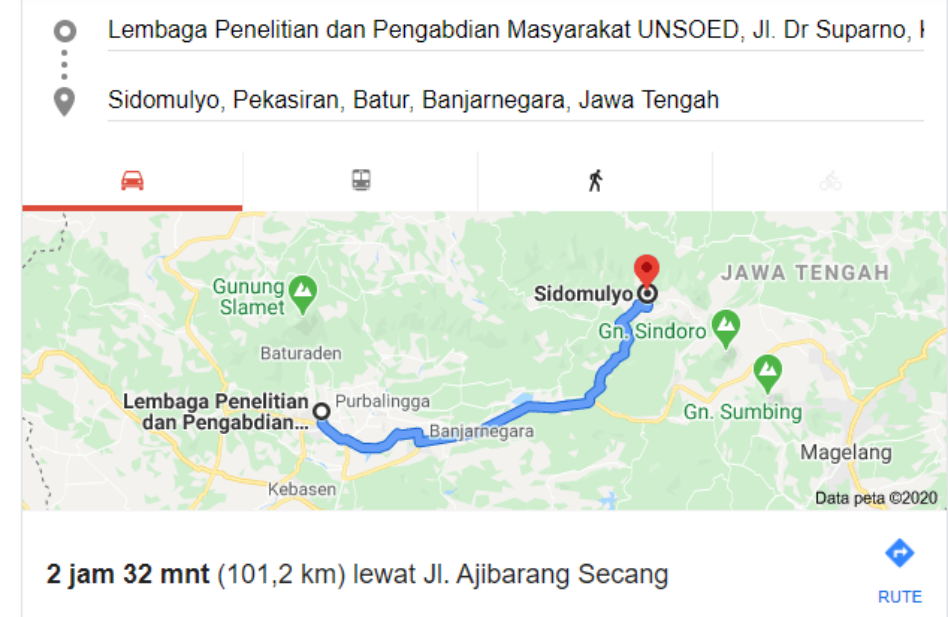

Gambar 3. Peta lokasi kegiatan

\subsection{Alat dan Bahan}

Alat dan bahan yang digunakan pada kegiatan transfer teknologi ini yaitu, materi transfer teknologi dalam power point yang berisi tahap-tahap produksi benih kentang secara aeroponik, demplot instalasi aeroponik (kerangka dari besi,dinding box dari kayu, penutup 
bagian atas box aeroponik menggunakan styrofoam, dan rockwoll), nutrisi $A B$ mix untuk aeroponik benih kentang dari hasil paten nutrisi dengan nomor paten IDP000065162, alat ukur nutrisi tanaman yaitu EC meter dan $\mathrm{pH}$ meter serta alat pengukur suhu dan kelembaban di dalam greenhouse, bibit kentang yang siap pindah tanam dan greenhouse untuk penempatan instalasi aeroponik.

\subsection{Metode dan Pelaksanaan}

Transfer teknologi ini dilakukan oleh tim pengabdian kepada masyarakat pada skema Penerapan IPTEK, Universitas Jenderal Spedirman untuk membantu kelompok Tani Mulya Bersama yang berada di lokasi sentra Kentang, Kabupaten Banjarnegara, Propinsi Jawa Tengah. Program transfer teknologi dilakukan selama 3 bulan. Kegiatan tersebut meliputi : penyampaian materi berkaitan tahap-tahap dan hal penting dalam produksi benih kentang serta gambaran instalasi aeroponik, demplot instalasi aeroponik, praktik pengelolaan nutrisi untuk produksi benih kentang secara aeroponik, penanaman bibit kentang pada instalasi aeroponik dan pendampingan selama pertumbuhan dan perkembangan tanaman.

\subsubsection{Transfer Teknologi Mengenai Tahap-Tahap Produksi Benih Kentang Secara Aeroponik dan membuat demplot}

Transfer teknologi produksi benih secara aeroponik dilakukan oleh tim Penerapan IPTEKS Universitas Jenderal Soedirman pada kelompok tani Mulya Bersama, Desa Sidamulyo, Banjarnegara dimulai dengan pengenalan dan pengetahuan tentang sistem aeroponik produksi benih kentang, kemudian dilakukan praktek langsung pembuatan box aeroponik (Gambar 4). Instalasi aeroponik merupakan bantuan dari tim pengabdi Universitas Jenderal Soedirman melalui skema Penerapan IPTEK. Transfer teknologi aeroponik untuk produksi benih kentang juga didukung kerjasama dengan kelompok Tani Mulya Bersama dalam bentuk penyediaan greenhouse sebagai sarana penempatan instalasi aeroponik. Evaluasi transfer teknologi dilakukan dengan Pre dan post test.

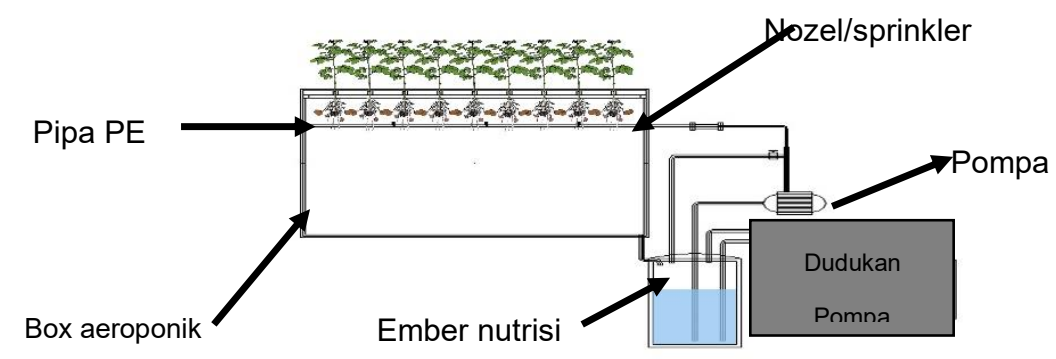

Gambar 4. Sistem aeroponik untuk produksi benih kentang yang akan dilakukan.

\subsubsection{Transfer Teknologi Pengelolaan Nutrisi untuk Produksi Benih Kentang secara Aeroponik untuk Menghasilkan Umbi/Benih Kentang}

Transfer teknologi ini dilakukan melalui pendampingan dan praktik langsung pengelolaan nutrisi dari membuat larutan stok dan larutan siap siram. Nutrisi yang digunakan adalah nutrisi dari hasil paten tim Unsoed [10]. Kelompok tani Mulya Bersama dilatih dari melarutkan nutrisi, pengecekan nutrisi sesuai dengan Electric Conductivity (EC) dan pH sesuai pertumbuhan dan perkembangan tanaman kentang secara aeroponik. Selanjutnya praktik pengelolaan nutrisi tersebut digunakan untuk aplikasi pada penampung nutrisi yang akan digunakan pada sistem aeroponik.

\subsubsection{Pindah Tanam Bibit Aeroponik dan Pengamatan Pertumbuhan dan Perkembangan Tanaman}

Bibit kentang untuk diaplikasikan di instalasi aeroponik merupakan bibit kentang dari kelompok Tani Mulya Bersama dan telah memasuki umur siap dipindah tanam. Pengamatan pertumbuhan dan perkembangan tanaman dilakukan dengan mengamati tinggi tanaman dan jumlah daun selama penanaman. 


\section{Hasil dan Pembahasan}

\subsection{Penyampaian Materi Mengenai Tahap-Tahap Produksi Benih Kentang Secara Aeroponik dan Gambaran Instalasi Aeroponik Benih Kentang.}

Penyampaian materi mengenai tahap-tahap produksi benih kentang secara aeroponik di dalam greenhouse dan gambaran instalasi aeroponik dilakukan di kelompok Tani Mulya Bersama, di Dusun Sidomulyo, Desa Pekasiran, Kecamatan Batur, Banjarnegara dihadiri 10 orang perwakilan dengan narasumber dari tim pengabdian kepada masyarakat Universitas Jenderal Soedirman. Kegiatan ini dilakukan dengan protokol kesehatan (Gambar 5). Setelah penyampaian materi dilanjutkan serah terima bahan dan alat dari tim pengabdi Unsoed kepada kelompok tani Mulya Bersama untuk pembuatan instalasi aeroponik. Tahap ini dilakukan secara bersama-sama antara tim Unsoed dan kelompok tani Mulya Bersama. Materi transfer teknologi aeroponik untuk produksi benih kentang diberikan kepada Kelompok Tani Mulya Bersama dalam bentuk print out materi.

Box aeroponik yang dibuat berukuran panjang 6 meter dan lebar $1 \mathrm{~m}$. Kerangka instalasi aeroponik berbahan besi, sedangkan untuk dinding box aeroponik dan bahan penutup dari bahan styrofoam dengan ketebalan $3 \mathrm{~cm}$ (Gambar 6). Hasil kuisoner pre tes menunjukkan bahwa sebelum dilakukan penyampaian materi prosentase penyerapan informasi tentang produksi benih kentang secara aeroponik sebesar $5 \%$. Penyampaian materi melalui transfer teknologi dari hasil post test diperoleh bahwa pemahaman kelompok Tani Mulya Bersama mengenai tahapan produksi benih kentang secara aeroponik meningkat menjadi $85 \%$ (Gambar 7).

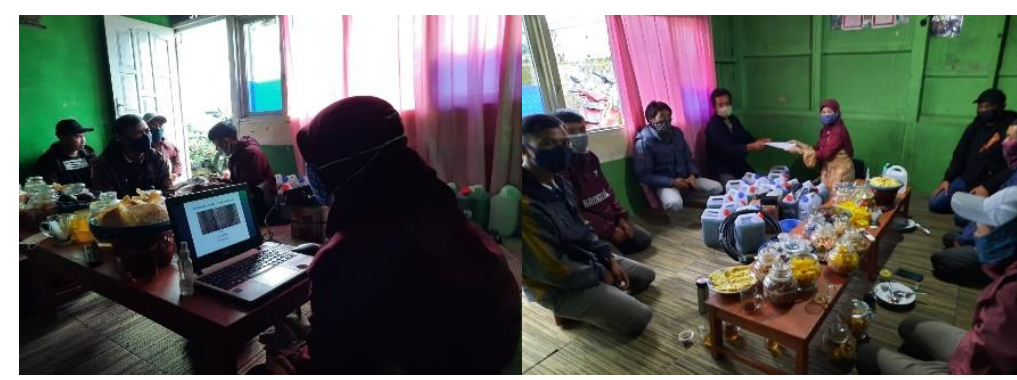

(a)

Gambar 5. Penyampaian materi produksi benih kentang secara aeroponik (a) dan serah terima bahan dan alat untuk pembuatan instalasi aeroponik (b)

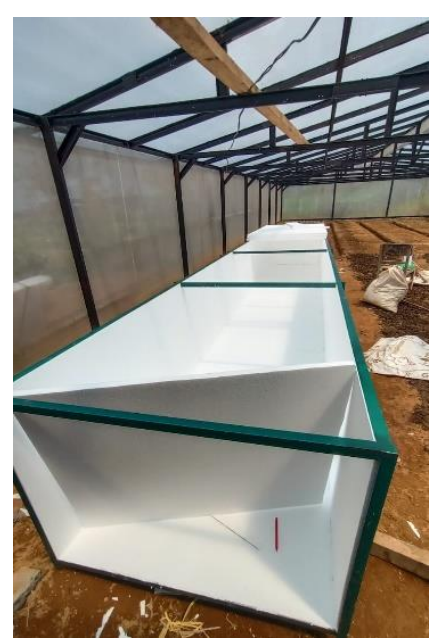

Gambar 6. Persiapan pembuatan instalasi box aeroponik untuk produksi benih kentang

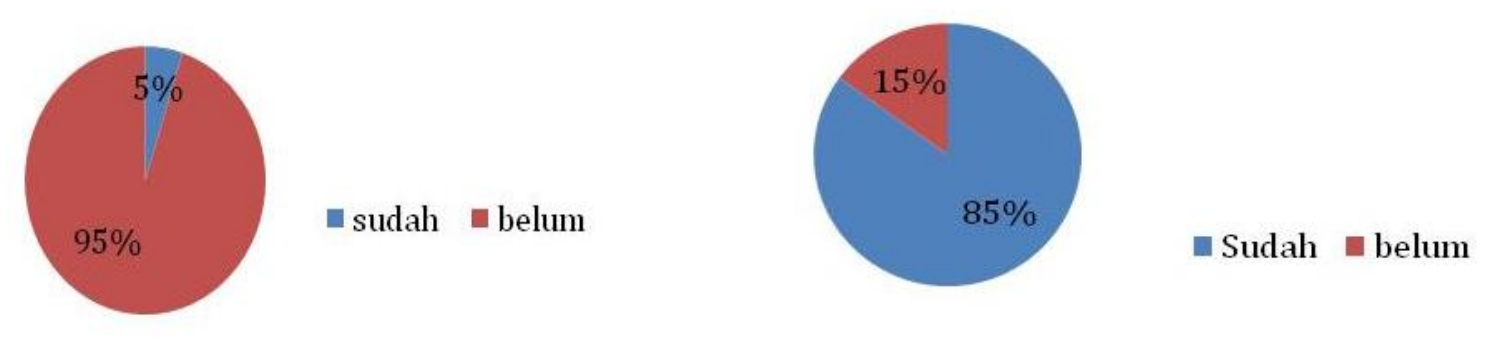


(a)

(b)

(a)

(b)

Gambar 7. Hasil Pre test (a) dan Post test pemahaman tentang teknologi aeroponik untuk produksi benih kentang (b)

\subsection{Transfer Teknologi Pengelolaan Nutrisi untuk Produksi Benih Kentang secara Aeroponik untuk Menghasilkan Umbi/Benih Kentang}

Pengelolaan nutrisi pada produksi benih kentang secara aeroponik menjadi salah satu faktor penting keberhasilan. Tanaman aeroponik yang mendapatkan nutrisi yang cukup dan sesuai perkembangan tanaman akan membantu tanaman menghasilkan benih umbi yang tinggi. Transfer teknologi ini dilakukan di kelompok Tani Mulya Bersama dengan melakukan praktik pengelolaan nutrisi. Transfer teknologi pengelolaan nutrisi ini diawali dengan pengisian pre test yang berkaitan dengan nutrisi untuk tanaman kentang aeroponik. Hasil pre test menunjukkan bahwa sebagian persen anggota kelompok tani belum mengerti penggunaan nutrisi untuk sistem aeroponik benih kentang (hasil pre test 3\%). Nutrisi yang digunakan merupakan nutrisi yang dihasilkan dari paten tim peneliti unsoed dengan no paten IDP000065162, nutrisi ini dibedakan menjadi nutrisi A dan nutrisi B untuk memudahkan dalam pengelolaanya. Sebelum diaplikasikan untuk penyiraman tanaman kentang di aeroponik disiapkan terlebih dahulu larutan stok dan kemudian disiapkan untuk larutan siap siram. Tahapan tersebut disajikan pada Gambar 8.

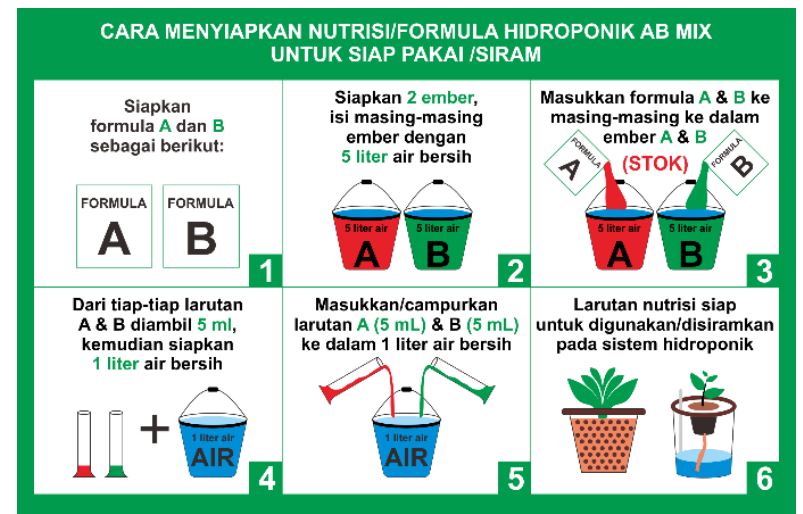

Gambar 8. Pengelolaan nutrisi untuk produksi benih kentang secara aeroponik [11]

Kunci penting pada pengelolaan nutrisi aeroponik yaitu kestabilan $\mathrm{pH}$ dan juga kepekatan larutan nutrisi yang diberikan kepada tanaman. Kepekatan larutan nutrisi disebut dengan EC (Electrical Conductivity). Alat ukur yang digunakan untuk mengontrol nutrisi adalah EC meter dan $\mathrm{pH}$ meter. Pertumbuhan tanaman aeroponik benih kentang yang baik apabila $\mathrm{pH}$ berada pada kisaran 5,5-6,5 dengan $\mathrm{pH}$ optimal 6 . Apabila larutan nutrisi kondisi pHnya dibawah 6 maka dapat dinaikkan supaya mencapai 6 dengan memberikan larutan basa kedalam larutan nutrisi untuk menaikkan $\mathrm{pH}$. Larutan $\mathrm{pH}$ yang dapat digunakan seperti $\mathrm{KOH}$ dan untuk penurun $\mathrm{pH}$ dapat digunakan $\mathrm{H}_{3} \mathrm{PO}_{4}$. Tanaman kentang yang masih muda dapat menggunakan EC yang rendah dan dinaikkan secara bertahap seiring dengan umur tanaman. Nilai EC yang terlalu rendah (terlalu encer) dari rencana yang diinginkan dilakukan penyesuaian dengan menambahkan larutan A dan larutan B masing masing dalam volume yang sama ke dalam ember/bak penampung nutrisi, sebaliknya bila EC terlalu tinggi dari 
yang direncanakan (terlalu pekat) maka dilakukan penambahan air kedalam ember/bak penampung nutrisi.

Tanaman yang baru pindah tanam menggunakan EC $1 \mathrm{mS} / \mathrm{cm}^{3}\left(1000\right.$ mikroSiemen $\left./ \mathrm{cm}^{3}\right)$ selama 2 minggu pertama, kemudian dinaikkan menjadi $1,5 \mathrm{mS} / \mathrm{cm}^{3}$ ketika tanaman memasuki umur 30 hari dan terus dinaikkan sesuai dengan umur tanaman untuk membantu pertumbuhan dan inisiasi umbi serta perkembangan umbi. Nilai EC maksimal yang digunakan untuk produksi aeroponik benih kentang yaitu $2 \mathrm{mS} / \mathrm{cm}^{3}$. Pengecekan nutrisi pada bak penampung nutrisi dilakukan setiap hari untuk memperoleh kondisi nutrisi yang optimal. Praktik pengelolaan nutrisi disajikan pada Gambar 8. Hasil post test dari kegiatan ini diperoleh informasi bahwa kelompok Tani Mulya Bersama mendaptakan peningkatan pengetahuan dan pengalaman dari kegiatan praktik langsung pengelolaan nutrisi, yaitu diperoleh hasil peningkatan pemahaman sebesar 87\% (Gambar 9).

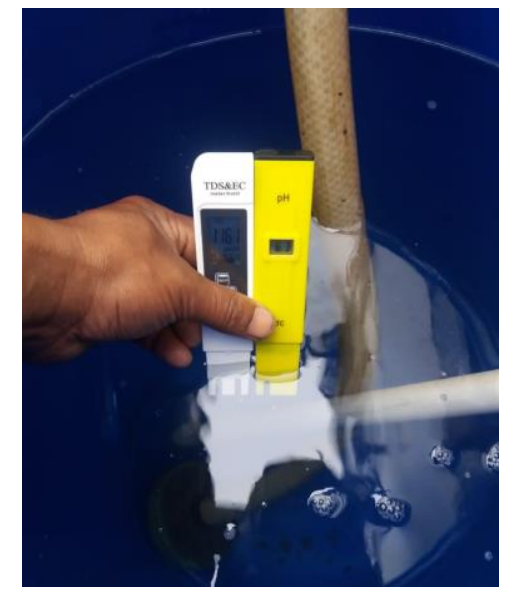

Gambar 9. Praktik pengelolaan nutrisi (EC dan $\mathrm{pH})$

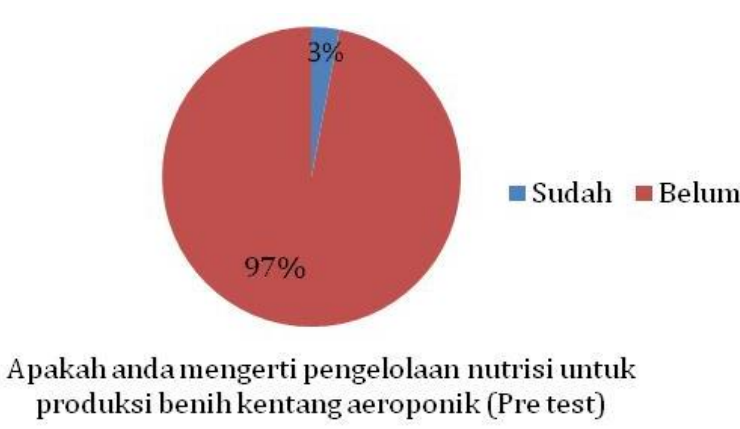

(a)

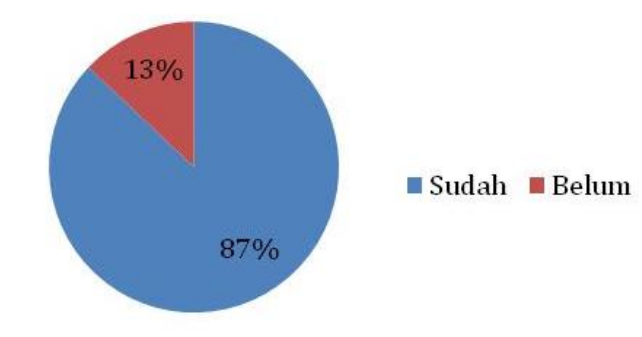

Apakah and a mengerti pengelolaan nutrisi untuk produksi benih kentang aeroponik (Post test)

(b)

Gambar 9. Hasil Pre test (a) dan Post test pemahaman tentang pengelolaan nutrisi pada teknologi aeroponik untuk produksi benih kentang (b)

\subsection{Pindah Tanam Bibit Aeroponik dan Pengamatan Pertumbuhan dan Perkembangan Tanaman}

Bibit kentang yang akan dipindah tanam ke dalam instalasi aeroponik merupakan bibit kentang yang sudah cukup umur untuk dilakukan pindah tanam ( \pm 3 minggu). Umur bibit kentang tersebut umumnya tanaman memiliki 5-7 helai daun dan diharapkan akar tanaman memiliki panjang minimal $5 \mathrm{~cm}$ sehingga memudahkan untuk mendapatkan semprotan nutrisi pada pertumbuhan awalnya. Bibit kentang yang digunakan pada kegiatan ini merupakan bibit yang dimiliki oleh kelompok Tani Mulya Bersama. Bibit kentang yan akan dipindahkan ke instalasi aeroponik dibalut dengan rockwoll (sebelumnya dicelupkan ke dalam larutan fungisida) dan kemudian dimasukan ke dalam netpot untuk diletakan di dalam instalasi aeroponik. Kegiatan pindah tanam dilakukan oleh Kelompok Tani Mulya Bersama dengan pemantauan dari tim pengabdian Unsoed. Kegiatan pindah tanam disajikan pada 
Gambar 10.

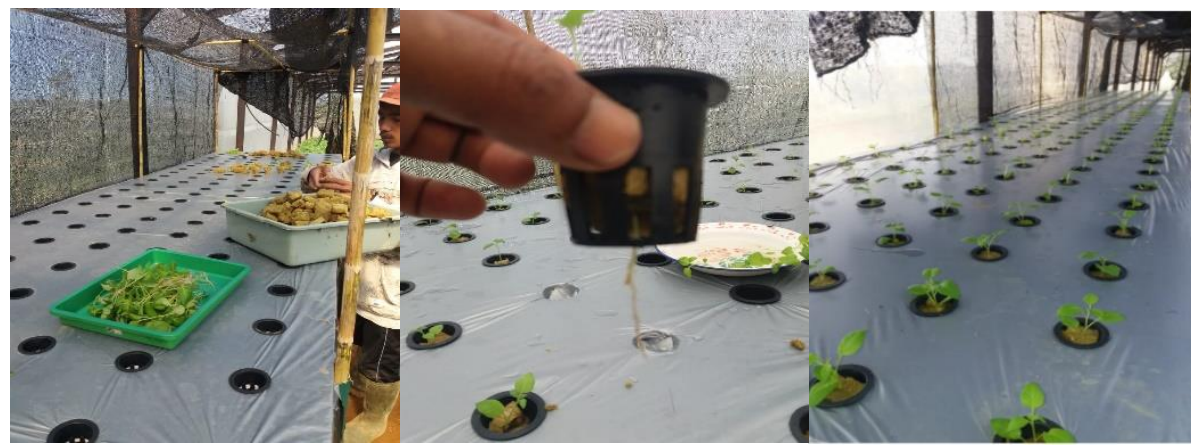

(a)

(b)

(c)

Gambar 10. Bibit kentang dibalut dengan rockwoll (a), bibit kentang dengan rockwoll dimasukan ke dalam netpot (b), (c) netpot diletakan dalam lubang styrofoam pada instalasi aeroponik

Pertumbuhan dan perkembangan bibit kentang pada instalasi aeroponik di dalam greenhouse dipengaruhi juga oleh iklim mikro yang tercipta di sekitar tanaman (greenhouse). Oleh karena itu di dalam greenhouse perlu ditempatkan alat suhu udara dan kelembaban untuk mengetahui kondisi cuaca di dalam greenhouse. Kondisi greenhouse yang panas (suhu $>30^{\circ} \mathrm{C}$ ) dan suhu nutrisi di bak penampung $>20^{\circ} \mathrm{C}$ selama pertumbuhan dapat mengganggu pertumbuhan dan perkembangan tanaman kentang maupun inisiasi umbi kentang. Oleh karena itu greenhouse yang dibangun perlu memperhatikan akses sirkulasi udara untuk menjaga suhu udara tetap nyaman bagi pertumbuhan tanaman kentang. Permasalahan yang dihadapi yaitu konstruksi greenhouse yang dimiliki oleh kelompok Tani Mulya Bersama memiliki tinggi yang belum optimal, yaitu sekitar $2 \mathrm{~m}$ dan sirkulasi udara yang belum baik. Hal itu disebabkan bentuk greenhouse yang tertutup dan akses bukaan ventilasi yang kurang optimal. Kondisi tersebut menyebabkan suhu udara di dalam greenhouse tinggi pada siang hari (mencapai $31^{\circ} \mathrm{C}$ ) dan juga bahan bak penampung nutrisi yang belum dapat meredam suhu tinggi, sehingga suhu nutrisi dapat mencapai lebih dari $25^{\circ} \mathrm{C}$.

Namun demikian, Kelompok Tani Mulya Bersama memberikan dukungan yang baik untuk transfer teknologi ini, sehingga berbagai upaya dilakukan dalam rangka menciptakan iklim mikro yang optimal untuk pertumbuhan dan perkembangan tanaman kentang aeroponik, yaitu dengan memasang paranet diatas tanaman dan memasang kipas di dalam bak penampun nutrisi untuk menurunkan suhu nutrisi. Pertumbuhan dan perkembangan tanaman dapat diamati setiap 7 hari yang meliputi tinggi tanaman, jumlah daun. Produksi benih kentang secara aeroponik memungkinan petani melihat perkembangan umbi pasa saat masa generatifnya, yaitu dengan mengecek kondisi akar dibawah styrofoam. Pertumbuhan dan perkembangan tanaman dari transfer teknologi ini disajikan pada Gambar 11 dan Gambar 12.

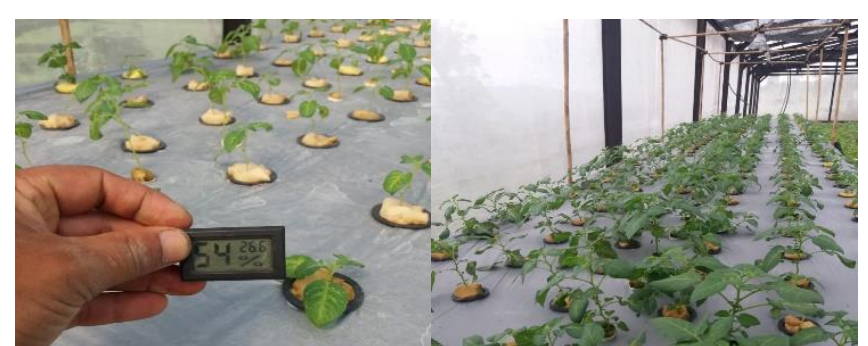


(a)

Gambar 11. Kondisi iklim mikro di dalam greenhouse dikektahu dengan alat ukur suhu dan kelembaban udara (a), perkembangan tanaman setelah 30 HST (Hari Setelah Tanam) (b).

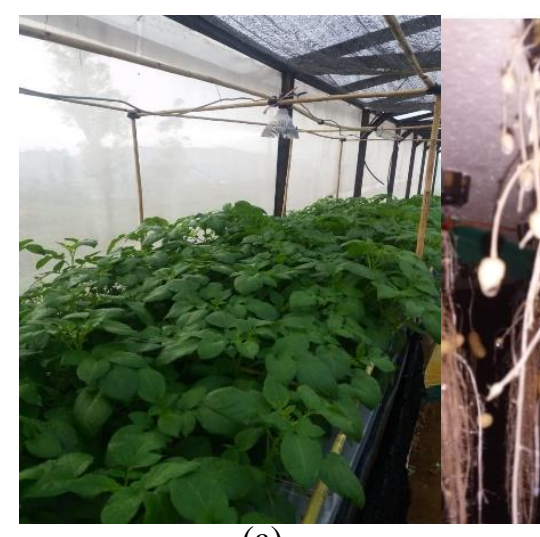

(a)

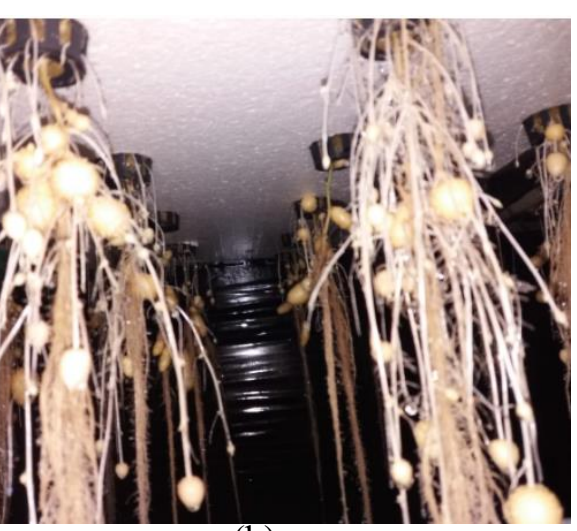

(b)

Gambar 12. Pertumbuhan tanaman setelah 70 HST (a), perkembangan umbi benih kentang (b)

\subsection{Keberlanjutan Program}

Produksi benih kentang melalui metode konvensional yang sebelumnya dilakukan oleh Kelompok Tani Mulya Bersama diperoleh 5-7 umbi per tanaman. Perkembangan umbi dari hasil transfer teknologi aeroponik pada umur 70 HST sudah ada yang mencapai 30 umbi pertanaman. Benih kentang aeroponik akan dipanen minimal 80 HST-100 HST, sehingga jumlah benih masih akan bertambah dan berkembang sampai waktu panen. Teknologi aeroponik untuk produksi benih kentang telah melalui kajian dari tim pengabdi Unsoed dan dapat memperoleh benih umbi $>25$ umbi/tanaman. Hal ini menunjukkan bahwa teknologi aeroponik untuk produksi benih kentang secara aeroponik memiliki potensi peningkatan jumlah benih kentang.

Kelompok Tani Mulya Bersama berusaha secara simultan memperbaiki permasalahan berkaitan dengan iklim mikro di dalam greenhouse dan berencana akan menambah jumlah box aeroponik sebanyak 4 buah secara mandiri dengan ukuran panjang $40 \mathrm{~m}$ untuk produksi benih kentang secara aeroponik pada masa tanam berikutnya (setelah kegiatan transfer teknologi dari Unsoed selesai). Hal ini dilakukan sebagai dukungan dari kelompok Tani Mulya bersama untuk keberlanjutan transfer teknologi produksi benih kentang secara aeroponik. Kelompok Tani Mulya Bersama memiliki harapan pada teknologi produksi benih kentang secara aeroponik ini dapat menjadi solusi untuk menghasilkan benih kentang dalam jumlah banyak, sehat dan terhindar dari penyakit tular tanah yang endemik di Banjarnegara.

\section{Kesimpulan}

Kegiatan transfer teknologi produksi benih kentang secara aeroponik yang dilakukan oleh tim pengabdian kepada masyarakat Unsoed melalui skema Penerapan IPTEKS mendapatkan respon yang baik dan juga dukungan dari Kelompok Tani Mulya Bersama, 
Dusun Pekasiran, RT.04/RW05, Kecamatan Batur, Kabupaten Banjarnegara, Jawa Tengah. Pemahaman trasfer teknologi ini mengalami peningkatan mencapai $85-87 \%$ dari sebelumnya 3-5\%. Kelompok tani dapat membuat demplot sistem aeroponik, melakukan kontrol untuk pengelolaan nutrisi, pindah tanam dan melakukan perawatan tanaman kentang pada instalasi aeroponik beserta iklim mikro di dalam greenhouse. Upaya keberlanjutan transfer teknologi ini mendapat dukungan dari Kelompok Tani Mulya Bersama dengan melakukan penambahan box aeroponik untuk memperluas produksi benih kentang secara aeroponik sebanyak 4 box sepanjang $40 \mathrm{~m}$. Komunikasi terhadap proses produksi selanjutnya tetap dilaksanakan antara tim pengabdi dari Unsoed dan Kelompok Tani Mulya Bersama meskipun kegiatan transfer teknologi telah selesai. Kelompok Tani Mulya Bersama memiliki harapan bahwa teknologi aeroponik untuk produksi benih kentang dapat menjadi solusi peningkatan jumlah benih kentang, dihasilkan benih yang sehat, jelas varietas dan juga kemudahan panen karena umbi dapat dilihat perkembanganya tanpa merusak tanaman. Transfer teknologi ini dapat dilakukan oleh anggota Kelompok Tani lainnya dan para penangkar kentang di sentra kentang Banjarnegara melalui pengembangan, sehingga dapat membuka produsen-produsen benih dan meningkatkan produksi benih kentang secara nasional.

\section{Ucapan Terima kasih}

Ucapan terima kasih disampaikan kepada : 1) Lembaga Penelitian dan Pengabdian Kepada Masyarakat, Universitas Jenderal Soedirman atas biaya yang diberikan untuk kegiatan transfer teknologi melalui skema Penerapan IPTEK tahun 2021 dengan kontrak No: 1183/UN23/HK.02/2021, 2) Kelompok Tani Mulya Bersama, Dusun Pekasiran, RT.04/RW 05, Kecamatan Batur, Kabupaten Banjarnegara yang telah menjadi mitra pada transfer teknologi ini.

\section{Daftar Pustaka}

[1] Otazu, V. 2010. Manual on quality seed potato production using aeroponics. International Potato Center (CIP). Lima. Peru. 44p.

[2] Correa RM, Pinto JEBP, Pinto AABP, Faquin V, Reis ES, Monteiro AB, Dyer WE. 2008. A comparison of potato seed tuber yields in beds, pots and hydroponic systems. Scientia Horticulturae. 116:17-20.

[3] Factor, T. L., J. AC. D. Araujo, F. P. C. kawakami, V. lunck. 2006. Potato basic minitubers production in three hydroponic system. Hortic. Bras. vol.25 no.1. Brasília Jan./Mar. 2006.

[4] Farran, I. , M. Castel M. 2008. Potato minituber production using aeroponics: effect of plant density and harvesting intervals. American Journal of Potato Research, Vol.83, No.1, p.47-53.

[5] Ritter, E., B. Angulo, C. Herran C, J. Relloso J, M.S. Jose. 2000. Comparison of hidroponic and aeroponic cultivation systems for the production of potato minitubers. Potato research 44:127-135.

[6] Sumarni, E., H. Suhardiyanto, K.B. Seminar, S.K. Saptomo 2013. Aplikasi pendinginan zona perakaran (Root Zone Cooling) pada produksi benih kentang menggunakan sistem aeroponik. J. Agron. Indonesia 41:154-159.

[7] Sumarni, E., N. Farid, Darjanto, Ardiansyah, and L. Soesanto. 2019a. Effect of Electrical Conductivity (EC) in the Nutrition Solution on Aeroponic Potato Seed Production with Root Zone Cooling Application in Tropical Lowland, Indonesia. AgricEnglnt: CIGR Journal Open access at http://www.cigrjournal.org. Vol. 21, No. 2. Pp:70-77.

[8] Sumarni, E., L. Soesanto, A. Widhiatmoko, Priswanto. 2019b. The effect of combination lighting of LED and neon light on the growth and yield of potato seeds on the production of Aeroponic seeds in the tropical highland. Agric Eng Int: CIGR Journal Vol.21.No.4:115-120.

[9] Sumarni, E., N. Farid, A. N. Sugiarto, A. Sudarmadji. 2016. G0 Seed Potential of The Aeroponics Potatoes Seed In The Lowlands With A Root Zone Cooling Into G1 In The Highlands. Rona Teknik Pertanian, 9(1) April 2016.

[10] Sumarni, E dan N. Farid. 2019. Nutrisi aeroponik benih kentang untuk daerah tropika basah. Paten granted. No. Sertifikat: IDP000065162 tertanggal 10 Desember 2019. Dirjen HKI. Jakarta. 
[11] Sumarni, E. dan N. Farid. 2016. Produksi Sayuran Bebas Pestisida dengan Hidroponik dalam Greenhouse. Buku Teknologi Tepat Guna. ISBN : 978-602-1643-25-9. LPPM. Unsoed. Purwokerto. Jawa Tengah.

[12] Gunawan dan Afrizal. 2009. Teknologi aeroponik terobosan perbanyakan cepat benih kentang. Jurnal Iptek hortikultura. No. 5:16-22. September. 